ORIGINAL ARTICLE

\title{
Dynamics in the soil, weed control and selectivity of sulfentrazone for eucalyptus
}

\author{
Dinâmica no solo, controle de plantas daninhas e seletividade do sulfentrazone \\ para o eucalipto
}

Caio Antonio Carbonari ${ }^{1}$ (D), Fabio Henrique Krenchinski ${ }^{1}$ (D), Giovanna Larissa Gimenes Cotrick Gomes ${ }^{1}$ (D), Plinio Saulo Simões ${ }^{1}$ (D), Gilmar José Picoli Junior ${ }^{1}$ [D, Edivaldo Domingues Velini' ${ }^{1}$ (])

${ }^{1}$ Universidade Estadual Paulista "Júlio de Mesquita Filho" - UNESP. Botucatu, SP, Brasil

How to cite: Carbonari, C. A., Krenchinski, F. H., Gomes, G. L. G. C., Simões, P. S., Picoli Junior, G. J., \& Velini, E. D. (2020). Dynamics in the soil, weed control and selectivity of sulfentrazone for eucalyptus. Scientia Forestalis, 48(126), e3398. https://doi.org/10.18671/scifor.v48n126.23

\begin{abstract}
Weed control and selectivity of sulfentrazone for eucalyptus is directly related to its dynamics in the soil in different application modes. The objective of this work was to evaluate the dynamics of sulfentrazone applied at different rates, in different soil types, and with different application modes, the weed control, and the injuries to eucalyptus plants of different clones. Field experiments were conducted in Itatinga and in Paranapanema, in the state of São Paulo, Brazil, on sandy and clayey soils, respectively. The different sulfrentrazone rates ( 300 and $400 \mathrm{~g} \mathrm{ha}^{-1}$ - sandy soil and 500 and $600 \mathrm{~g} \mathrm{ha}^{-1}$ - clayey soil) were applied before and after subsoiling of the planting row in total area. Sulfrentrazone contents were quantified in soil samples of the 0-20 and $20-40 \mathrm{~cm}$ layers in the planting row and inter-row, using a Liquid Chromatography Mass/Mass (LC-MS/MS) system. Injuries on the eucalyptus plants and weed control were also evaluated. The sulfrentrazone contents in the soil were proportional to the applied rates, regardless of the soil, in the 27 and 70 DAA (days after application) (clayey) and 16 and 48 DAA (sandy) evaluations. In the first evaluations, the application of sulfentrazone before subsoiling resulted in a lower content of this herbicide in the planting row, compared to the application after subsoiling, but the contents were similar in the last evaluations (109 and 140 DAA). Weed control by the herbicide at the higher rates was better in the sandy soil $\left(400 \mathrm{~g} \mathrm{ha}^{-1}\right)$ than in the clayey soil $\left(600 \mathrm{~g} \mathrm{ha}^{-1}\right)$. No injuries to the tested Eucalyptus grandis clones (SF, SP1048, SP1049 and SP0791) were found under the study conditions. The sulfrentrazone dynamics is initially affected by the application mode, but it does not affect its weed control and selectivity for eucalyptus.
\end{abstract}

Keywords: Adsorption; Sorption; Herbicide dynamics; Leaching.

\section{Resumo}

O controle de plantas daninhas e a seletividade do sulfentrazone em eucalipto está diretamente relacionada à sua dinâmica no solo em diferentes modalidades de aplicação. Os objetivos foram avaliar a dinâmica do sulfentrazone aplicado em diferentes doses, tipos de solo e modalidades de aplicação, além de avaliar o controle de plantas daninhas e injúrias em diferentes clones de eucalipto. Os experimentos foram instalados a campo em Itatinga-SP e Paranapanema-SP com solo de textura arenosa e argilosa, respectivamente. As diferentes doses (300 e $400 \mathrm{~g} \mathrm{ha}^{-1}$ - arenosa e 500 e $600 \mathrm{~g} \mathrm{ha}^{-1}$ - argilosa) de sulfentrazone foram aplicadas antes e após a subsolagem da linha de plantio em área total. As contrações de sulfentrazone foram quantificadas por um sistema de cromatografia liquida massa/massa(LC-MS/MS), em coletas realizadas na linha e entre linha, nas profundidades de 0-20 e 20$40 \mathrm{~cm}$. Foram avaliados ainda a injúria nas plantas de eucalipto e o controle de plantas daninhas. As contrações de sulfentrazone no solo foram proporcionais as doses aplicadas, independente do solo, nas

Financial support: São Paulo Research Foundation funded this research - FAPESP - Number: 2015/09390-1.

Conflict of interest: Nothing to declare.

Corresponding author: fhkrenchinski@gmail.com

Received: 31 May 2019

Accepted: 23 July 2019

Editor: Francides Gomes da Silva Júnior.

(c) This is an Open Access article distributed under the terms of the Creative Commons Attribution License, which permits unrestricted use,

c) distribution, and reproduction in any medium, provided the original work is properly cited. 
coletas de 27 e 70 DAA (Solo argiloso) e 16 e 48 DAA (Solo arenoso). A aplicação de sulfentrazone antes da subsolagem resultou em menor concentração desse herbicida na linha de plantio, nas primeiras coletas em comparação com a aplicação após a subsolagem, porém ficaram semelhantes para as coletas de 109 e 140 DAA. O controle de plantas daninhas foi maior nas doses aplicadas no solo arenoso $\left(400 \mathrm{~g} \mathrm{ha}^{-1}\right)$ em relação ao solo argiloso (600 $\left.\mathrm{g} \mathrm{ha}^{-1}\right)$. Não foram observadas injúrias nos clones de Eucalyptus grandis (SF, SP1048, SP1049 e SP0791) em ambas as condições. O sulfentrazone é afetado inicialmente de acordo com a modalidade de aplicação, porém isso não influência o controle de plantas daninhas e a seletividade no eucalipto.

Palavras-chave: Adsorção; Sorção; Dinâmica de herbicidas; Lixiviação.

\section{INTRODUCTION}

Eucalyptus plantations are important in Brazil; they generate raw material for cellulose, paper, coal, furniture, and energy production. The area with planted forests in Brazil reached 7.84 million hectares in 2017, with 5.7 million hectares (72.7\%) of eucalyptus (Indústria Brasileira de Árvores, 2017).The greatest areas are in the states of Minas Gerais (24\%), São Paulo (17\%), and Mato Grosso do Sul (17\%) (Indústria Brasileira de Árvores, 2017). Eucalyptus plantations are important for the country's economy, and are promising for renewable energy, recovery of degraded areas and atmospheric $\mathrm{CO}_{2}$ sequestration (Olivette et al., 2011).

Weeds compete with eucalyptus plants for light, water, and nutrients and are one of the main problems for implementation and maintenance of eucalyptus plantations (Medeiro et al., 2016). This competition is higher in the first two years after planting, when the plants are at the initial stage of development. The effects of weeds on eucalyptus plantations depend on the composition and density of the weed community (Garau et al., 2009). Annual weed species, such as Panicum maximum, Urochloa spp., Ipomoea spp., Commelina spp., and Spermacoce latifolia compete with eucalyptus plants at the initial stages of growth (Medeiro et al., 2016; Ferreira et al., 2016; Cruz et al., 2010). Weed management in eucalyptus plantations is an important cultural practice that has direct effects on yield and production costs (Machado et al., 2009). One of the most used practices to control weeds is the use of chemical herbicides.

Sulfentrazone is one of the herbicides used in eucalyptus plantations; it inhibits the protoporphyrinogen oxidase (PROTOX), causing the accumulation of protoporphyrinogen IX and formation of singlet oxygen, which is responsible for the peroxidation of cell membranes (Scalla et al., 1990). Sulfentrazone has a water solubility of $490 \mathrm{mg} \mathrm{L}^{-1}$ and a vapor pressure of $1 \times 10^{-9} \mathrm{~mm} \mathrm{Hg}$ at $25^{\circ} \mathrm{C}$ and is approved for controlling mono- and dicotyledonous weeds in eucalyptus at pre-emergence (Rodrigues and Almeida, 2011).This herbicide has moderate mobility in the soil, with great leaching potential in sandy soils (Melo et al., 2010; Monquero et al., 2010). It presents low adsorption, mainly in clayey soils and soils with high organic matter content, which slows the desorption process (Martinez et al., 2008; Reddy \& Locke, 1998). The microbial decomposition is the main route of degradation of sulfentrazone (Martinez et al., 2010, 2008; Shaner, 2012), with a half-life of 180 days (Rodrigues \& Almeida, 2011).

Minimum cultivation for eucalyptus consists in soil rotation only for the planting row; it has been used in forest plantations (Gatto et al., 2003). Herbicide applications, especially at pre-emergence, can be carried out under these conditions before or after subsoiling of the planting row, which may affect the weed control, dynamics, and selectivity of these herbicides. Thus, studies on herbicides applied under these conditions are important for the forestry sector to ensure weed control with long residual effect, selectivity for eucalyptus seedlings, and safety for the environment. Sulfentrazone dynamics is dependent on soil textures and managements (Reddy \& Locke, 1998; Carbonari et al., 2016b). Sulfentrazone can be leaching, especially when applied to sandy soils (Melo et al., 2010; Monquero et al., 2010) and higher adsorption and slower desorption rate of the clayey soils (Paranapanema) (Martinez et al., 2008; Reddy \& Locke, 1998).

The objective of this work was to evaluate the dynamics of sulfentrazone applied at different rates, in different soil textures, with different application modes (before and after 
subsoiling of the planting row), the weed control, and the effects of sulfentrazone on initial development of different eucalyptus clones.

\section{MATERIAL AND METHODS}

Two field experiments were conducted in areas with eucalyptus plantations: on a sandy soil in Itatinga and on a clayey soil in Paranapanema, in the state of São Paulo, Brazil. Soil samples of the $0-20 \mathrm{~cm}$ layer were collected and analyzed; the soils of Itatinga and Paranapanema presented 14 and $25 \mathrm{~g} \mathrm{dm}^{3}$ of organic matter, CEC of 95 and $118 \mathrm{mmolc} \mathrm{dm}^{-3}$, base saturation of 7 and $10 \%$, and sandy ( $83 \mathrm{~g} \mathrm{~kg}^{-1}$ of clay, $2 \mathrm{~g} \mathrm{~kg}^{-1}$ of silt, and $915 \mathrm{~g} \mathrm{~kg}^{-1}$ of sand) and clayey (514 $\mathrm{g} \mathrm{kg}^{-1}$ of clay, $170 \mathrm{~g} \mathrm{~kg}^{-1}$ of silt, and $316 \mathrm{~g} \mathrm{~kg}^{-1}$ of sand) texture, respectively.

A randomized block experimental design was used, with four replications. The treatments consisted of sulfentrazone application before and after subsoiling (Table 1). Four different Eucalyptus grandis clones were planted in both experiments: SF, SP1048, SP1049, and SP0791. Five seedlings of each clone were planted in each plot within the application area, with spacing of 3 meters between rows and 2 meters between plants, after Sulfentrazone application.

Table 1. Herbicides, time of application, and rates used in the treatments. Itatinga and Paranapanema, SP, Brazil.

\begin{tabular}{ccc}
\hline Treatments & \multicolumn{2}{c}{ Rates $\left(\mathbf{g ~ h a} \mathbf{~}^{-1}\right)$} \\
\cline { 2 - 3 } & Itatinga & Paranapanema \\
\hline Sulfentrazone after subsoiling & 300 & 600 \\
Sulfentrazone after subsoiling & 400 & 500 \\
Sulfentrazone before subsoiling & 300 & 600 \\
Sulfentrazone before subsoiling & 400 & 500 \\
Control & ---- & ---- \\
\hline
\end{tabular}

The treatments were applied in total area on four planting rows, and the soil, toxicity, and weed control evaluations were carried out using the two central rows. A hydraulic sprayer (Jacto brand, model Jatão 600) coupled to a tractor was used for the applications, using a solution volume of $150 \mathrm{Lha}^{-1}$. In Itatinga, the spraying was carried out with TTI 015 tips (Teejet ${ }^{\circledR}$, Wheaton, USA) spaced $0.4 \mathrm{~m}$ apart, pressure of $1.8 \mathrm{PSI}$, and speed of $4 \mathrm{~km} \mathrm{~h}^{-1}$. The applications before and after subsoiling were performed under temperatures of 28.8 and $31.5^{\circ} \mathrm{C}$, relative air humidity of $64.3 \%$ and $50.3 \%$, and wind speeds of 7 and $2.6 \mathrm{~km} \mathrm{ha}^{-1}$, respectively. In Paranapanema, the spraying was carried out with FV8-2.5 tips (Teejet, Wheaton, IL 60187, USA) spaced $0.96 \mathrm{~m}$ apart, pressure of $45.5 \mathrm{PSI}$, and speed of $4.8 \mathrm{~km} \mathrm{~h}^{-1}$. The applications before and after subsoiling were performed at temperatures of 24.1 and $23.9^{\circ} \mathrm{C}$, relative air humidity of $38.5 \%$ and $38 \%$, and wind speeds of 8.5 and $6.5 \mathrm{~km} \mathrm{ha}^{-1}$, respectively. The applications were carried out in March 2016 (Itatinga) and May 2016 (Paranapanema).

The sulfentrazone contents in the soil were determined in four soil samples of the 0-20 and 20-40 cm layers. In Itatinga, the samples were collected at 16, 48, 66, and 109 days after application of the herbicides (DAA), with accumulated rainfall depths between collections of $26,173,222$, and $401 \mathrm{~mm}$, respectively. In Paranapanema, the samples were collected at 27 , 70,97 and 140 DAA, with accumulated rainfall depths between collections of 19, 98, 121, and $177 \mathrm{~mm}$, respectively. The soil samples were collected in the planting row and inter-row for plots with sulfentrazone applications before subsoiling, and only in the planting row for plots with applications after subsoiling. Fifteen sample points per plot were used for each location (row and inter-row), making a composite sample per plot and location.

The samples were frozen $\left(-10^{\circ} \mathrm{C}\right)$ until analysis; then, they were homogenized and dried in a forced air circulation oven at $40^{\circ} \mathrm{C}$ for 48 hours or until constant weight. Aliquots of $7 \mathrm{~g}$ were taken and placed in cartridges with collectors in the lower part to collect the extracted material. The samples were saturated with 1.5 (sandy soil) and $3.0 \mathrm{~mL}$ (clayey soil) of distilled water and kept under saturation conditions for 24 hours. The samples were then centrifuged 
for $5 \mathrm{~min}$ at $4000 \times \mathrm{g}$, and the supernatant was filtered using Millipore filters of $0.2 \mu \mathrm{m}$ and transferred to vials.

The sulfentrazone content was quantified in a LC-MS/MS system, consisting of a highperformance liquid chromatograph (HPLC) (Prominence UFLC, Shimadzu), equipped with two LC20AD pumps, a SIL-20AC self-injector, a DGU-20A5 degasser, a CBM-20A controller system that allows fully automated operation, and a CTO-20AC oven for column temperature control. A 3200 Q TRAP mass spectrometer (Applied Biosystems), hybrid triple quadrupole was coupled to the HPLC. A Synergi Column $2.5 \mu$ Hydro RP $100 \AA$ was used with $0.5 \%$ acetic acid in water (Phase A FA) and $0.5 \%$ acetic acid in methanol (Phase B - FB). The gradients used were as follows: 0 - 1 minutes $=50 \% \mathrm{FB}$ and $50 \% \mathrm{FA} ; 1-3$ minutes $=95 \% \mathrm{FB}$ and $5 \% \mathrm{FA} ; 3-6$ minutes $=95 \% \mathrm{FB}$ and $5 \%$ $\mathrm{FA} ; 6-8$ minutes $=50 \% \mathrm{FB}$ and $50 \% \mathrm{FA}$, and $8-10$ minutes $=50 \% \mathrm{FB}$ and $50 \% \mathrm{FA}$, with a flow of 0.60 $\mathrm{mL} \mathrm{min} \mathrm{m}^{-1}$ and a reading time of 12 minutes.

The injuries to the clones caused by the herbicides were visually evaluated using percentages which varied on a scale $0 \%$ to $100 \%$, in which $0 \%$ represents plants without injury and $100 \%$ represents dead plants. The weed control in the planting row and inter-row in Itatinga, and in inter-row in Paranapanema was also visually evaluated using percentages which varied on a scale $0 \%$ to $100 \%$, with $0 \%$ representing no control and $100 \%$ representing total weed control when compared to the control treatment. The injury and control methodologies are described by Sociedade Brasileira da Ciência das Plantas Daninhas (1995). The main weed species found were Spermacoce latifolia, Commelina benghalensis, Brachiaria decumbens, Cyperus sp., Phytolacca thyrsiflora, and Emilia fosbergii in the area in Itatinga; and Brachiaria decumbens, Cyperus sp., and some broadleaf seedlings at early stage of development in the area in Paranapanema.

The data were subjected to the normality test of Shapiro-Wilk, and after analysis of variance (ANOVA) at $5 \%$ of probability; the standard error of the mean was calculated, and the data were represented in graphs as mean \pm standard error.

\section{RESULTS AND DISCUSSION}

The soil samples collected at 16 DAA in Itatinga had similar sulfentrazone contents in both evaluated soil layers $(0-20$ and $20-40 \mathrm{~cm})$. This indicates that this herbicide can leach to great soil depths soon after the first rains after its application; this was also found in other studies (Silva Junior et al., 2016; Carbonari et al., 2016a; Blanco et al., 2010). The application rate of $400 \mathrm{~g} \mathrm{ha}^{-1}$ of sulfentrazone resulted in a higher content of the herbicide in the soil than the rate of $300 \mathrm{~g} \mathrm{ha}^{-1}$, regardless of the application mode. The sulfentrazone application before subsoiling resulted in smaller contents of the herbicide in the eucalyptus planting row at 16 and 48 DAA, when compared to the application after subsoiling (Figure 1).

The sulfentrazone contents in the soil decreased after 66 DAA. However, application modes presented differences in the $0-20 \mathrm{~cm}$ layer; the sulfentrazone contents in the application after subsoiling was lower when compared to the application before subsoiling. The sandy soil of the area in Itatinga has lower sulfentrazone sorption capacity and the subsoiling allowed a greater soil water infiltration, favoring the leaching of sulfentrazone to deeper soil layers (Silva Junior et al., 2016; Passos et al., 2015). The application modes and rates resulted in similar sulfentrazone soil contents at 109 DAA (Figure 1).

The highest sulfentrazone rates in Paranapanema (clayey soil) resulted in higher sulfentrazone contents in the soil. At 27 DAA, the highest sulfentrazone contents in the planting row (after subsoiling) and inter-row (before subsoiling) were found in the $0-20 \mathrm{~cm}$ layer (Figure 2). This result is explained by the smaller accumulated rainfall depths in Paranapanema $(19 \mathrm{~mm})$ when compared to Itatinga $(26 \mathrm{~mm})$, which reduced the herbicide leaching to deeper soil layers. According to Melo et al. (2010), sulfentrazone leaching is higher as precipitation increases, especially in sandy soils, such as that of Itatinga. This is confirmed by several studies (Braga et al., 2016; Silva Junior et al., 2016; Monquero et al., 2010). The application after subsoiling resulted in the highest sulfentrazone contents in the planting row in the layer of $20-40 \mathrm{~cm}$ at 70 and 97 DAA. 


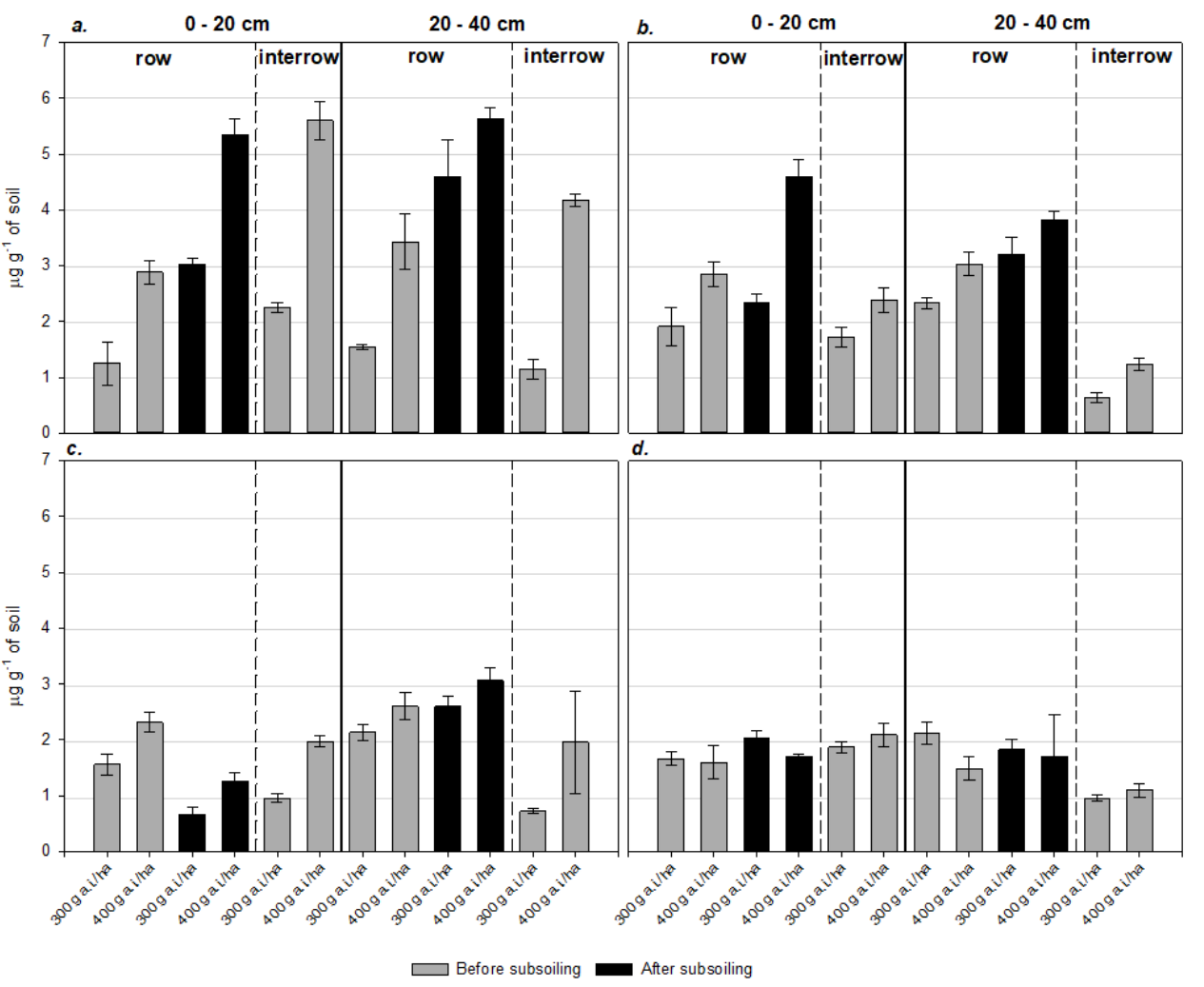

Figure 1. Sulfentrazone contents in the soil $\left(\mu \mathrm{g} \mathrm{g}^{-1}\right)$ in the $0-20$ and $20-40 \mathrm{~cm}$ layers, collected on the planting row and inter-row of eucalyptus plants at 16 (a), 48 (b), 66 (c), and 109 (d) days after application in Itatinga, SP, Brazil. (Mean \pm standard error).
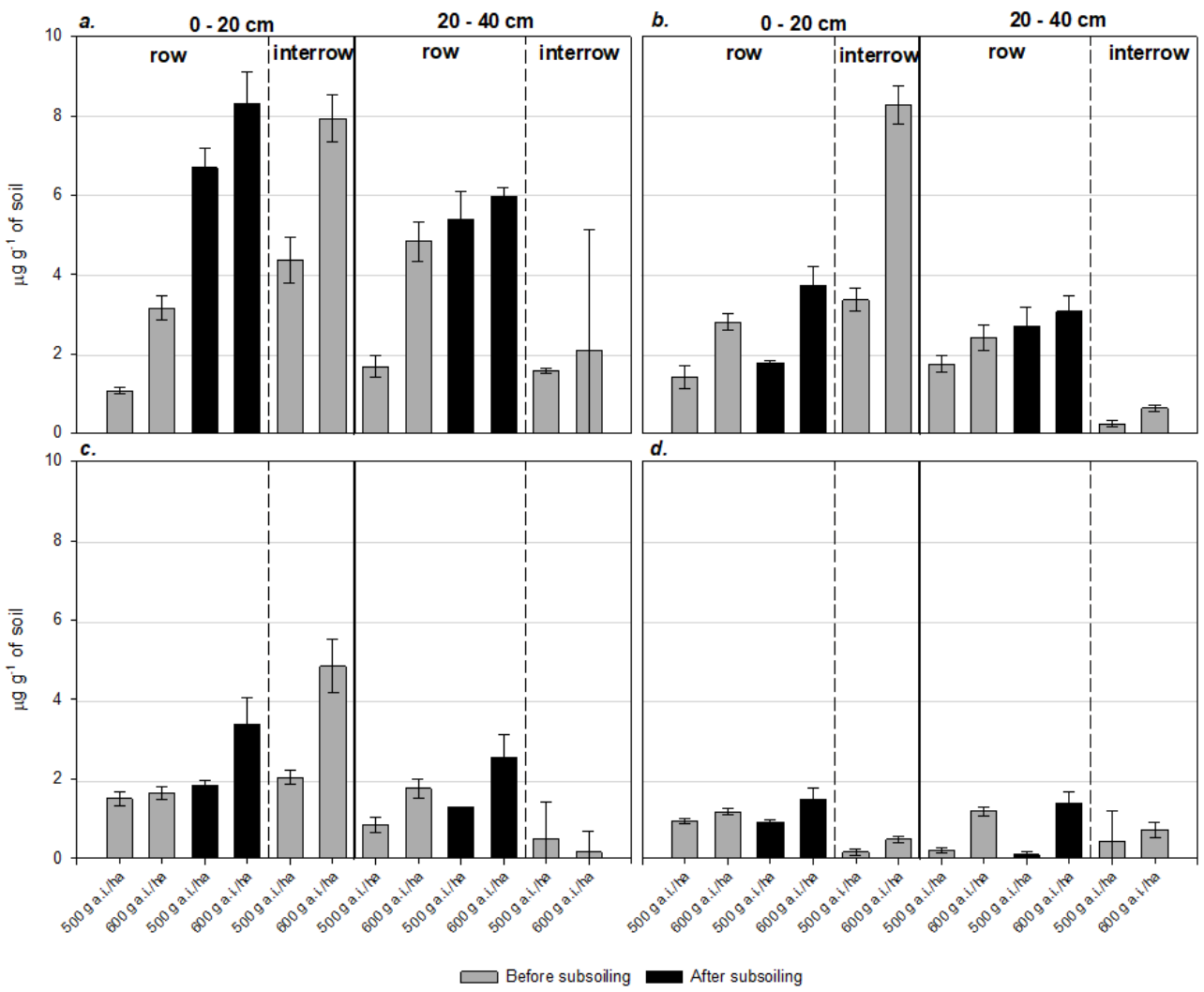

Figure 2. Sulfentrazone contents in the $0-20$ and $20-40 \mathrm{~cm}$ layers of soil $\left(\mu \mathrm{g} \mathrm{g}^{-1}\right)$ collected on the planting row and inter-row of eucalyptus plants at 27 (a), 70 (b), 97 (c), and 140 (d) days after application in Paranapanema, SP, Brazil. (Mean \pm standard error). 
The application of the highest sulfentrazone rate $\left(600 \mathrm{~g}\right.$ and $\left.\mathrm{ha}^{-1}\right)$ resulted in higher sulfentrazone contents in the soil, regardless of the application mode at 27, 70 and 97 DAA. Carbonari et al. (2016b) evaluated sulfentrazone rates (200,400, and $\left.600 \mathrm{~g} \mathrm{ha}^{-1}\right)$ in sandy and clayey soils and found that sulfentrazone contents in the soil are proportional to the applied rates.

Regarding the effects of the application modes, the application before subsoiling resulted in lower sulfentrazone contents in the eucalyptus planting row in all evaluated herbicide rates and soil layers.

The differences between sulfentrazone contents in the soil due to the application modes practically disappeared at 140 DAA. This explains the similar results in weed control. Thus, despite the initial higher herbicide contents in the soil with the application after subsoiling, no difference was found in the last evaluation, indicating the same residual period of this herbicide, regardless of the application mode (Figure 2). Carbonari et al. (2016b) evaluated sulfentrazone rates (200, 400, and $600 \mathrm{~g} \mathrm{ha}^{-1}$ ) applied in pots with sandy and clayey soils and found $80 \%$ lower sulfentrazone in the soil at 90 DAA when compared with that at 15 DAA, regardless of the herbicide rate and soil type. Moreover, Martinez et al. (2008) found 55\% lower sulfentrazone in the soil at 120 DAA, with a moisture condition of $30 \%$ of the soil field capacity.

Sulfentrazone contents in the soil decreased at each soil evaluation, regardless of the application mode and site of the experiment (Itatinga: 16, 48, 66, and 109 DAA; Paranapanema: $27,70,97$, and 140 DAA). This is evidence of a herbicide degradation in the soil, leaching to deeper non-sampled layers or sorption to soil colloids (Figure 3). However, the greatest reduction was found with applications after subsoiling. The reductions in sulfentrazone contents from the first (16 DAA) to the last (109 DAA) evaluation in Itatinga were 21\% (before subsoiling) and $60 \%$ (after subsoiling). This reduction was greater in the clayey soil (Paranapanema), with 75\% (before subsoiling) and 85\% (after subsoiling).

a.

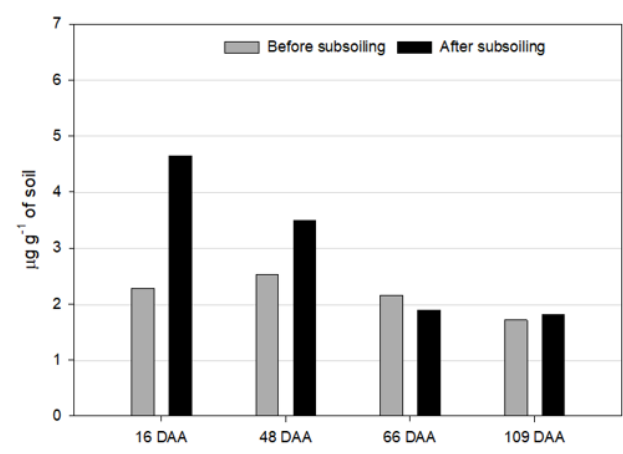

b.

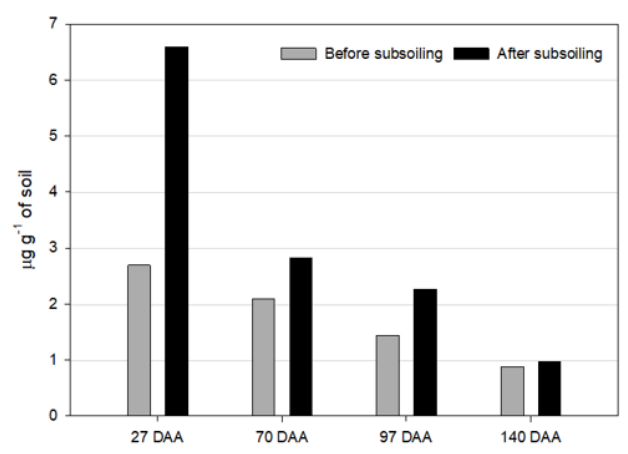

Figure 3. Mean sulfentrazone contents in the soil $\left(\mu \mathrm{g} \mathrm{g}^{-1}\right)$ with applications before and after subsoiling, in Itatinga, SP (a) and Paranapanema, SP (b), Brazil.

The reduction of sulfentrazone contents in the soil is explained by the leaching potential, especially when applied to sandy soils (Melo et al., 2010; Monquero et al., 2010), such as that in Itatinga. In addition, this area presented greater accumulated rainfall depts during the experiment, favoring leaching. The sulfentrazone contents in the soil decreased also due to the higher adsorption and slower desorption rate of the clayey soil (Paranapanema) (Martinez et al., 2008; Reddy \& Locke, 1998). According to Freitas et al., (2014), soils with higher organic matter present higher adsorption potential of sulfentrazone. The soil organic matter contents of the study areas were $14 \mathrm{~g} \mathrm{dm}^{3}$ (Itatinga) and $25 \mathrm{~g} \mathrm{dm}^{3}$ (Paranapanema); thus the adsorption would be higher for the area in Paranapanema, and the herbicide contents in the soil would decrease over time (Figure 3). In addition to the reduction of sulfentrazone by leaching (sandy soil) and adsorption (clayey soil), this herbicide is degraded by microorganisms, which reduces its contents over time (Martinez et al., 2010, 2008; Shaner, 2012). 
Subsoiling (soil turning) can reverse soil layers, distributing the herbicide when it is applied before subsoiling, thus lower contents of sulfentrazone are found in the soil. However, in this case, the herbicide is protected from losses by volatilization and photodegradation, remaining longer in the soil (Figure 3). When the herbicide is applied after subsoiling, it is lost by adsorption, leaching, microbial degradation, and photodegradation. Carbonari et al. (2016a) evaluated sulfentrazone contents in soils after applying it on sugarcane straw, without rainfall, and found $76.5 \%$ of the sulfentrazone applied after one day, $61.7 \%$ after 30 days, and $42.3 \%$ after 60 days; the sulfentrazone loss was attributed to photodegradation and interaction of the herbicide with the sugarcane straw. This may be the cause of the more pronounced sulfentrazone reductions found in the present study for application after subsoiling in both sites.

The eucalyptus clones presented low visual injury symptoms $(<3 \%)$ at 7 DAA when sulfentrazone was applied after subsoiling, and they did not persist in the other evaluations. Sulfentrazone was selective to eucalyptus in all conditions (data not shown). According to Carbonari et al. (2012), the selectivity of sulfentrazone for eucalyptus is due to the herbicide absorption; the clones that present higher absorption of sulfentrazone have more injuries and lower growth. However, this was not found in the present work.

Sulfentrazone presented greater weed control (>80\%) when applied at a rate of $400 \mathrm{~g} \mathrm{ha}^{-1}$ in the eucalyptus planting row, regardless the application mode (before or after subsoiling), up to 66 DAA in Itatinga. However, in the last evaluation (109 DAA), the control decreased $(<40 \%)$, regardless of the rate and application mode used (Figure 4 and 5). This result is associated with the reduction of sulfentrazone contents in the soil (Figures 1 and 3). Weed control in the eucalyptus inter-row was efficient (>80\%) at 48 and 66 DAA with both sulfentrazone rates only when applied before subsoiling, with a decrease in weed control at 109 DAA.

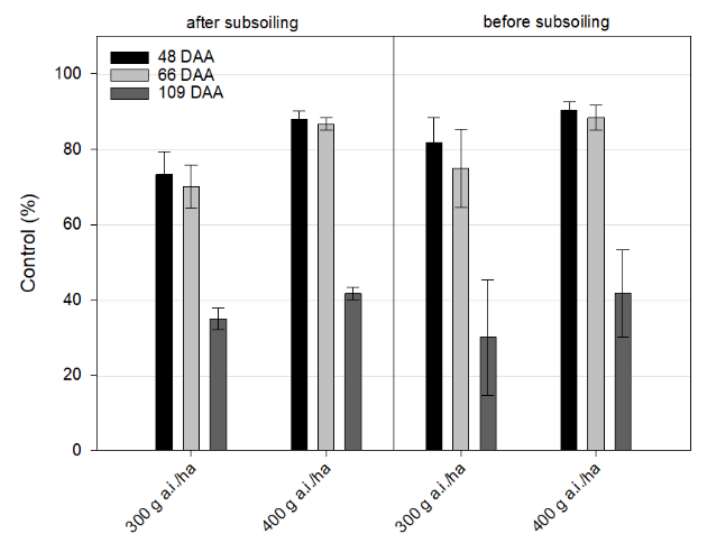

Figure 4. Percentage of weed control in the planting row, at 48, 66, and 109 days after application, in the area of Itatinga, SP, Brazil. (Means \pm standard error).

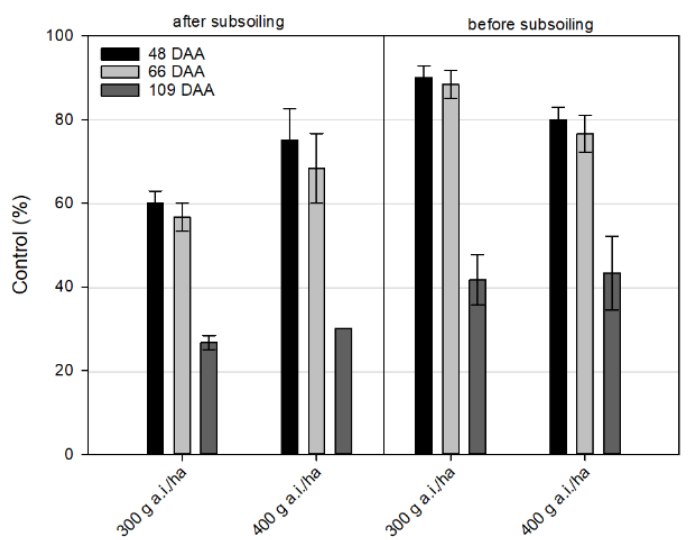

Figure 5. Percentage of weed control in the inter-row, at 48, 66 and 109 days after application, in the area in Itatinga, SP, Brazil. (Means \pm standard error). 
No weed infestation was observed in the planting row in the area in Paranapanema, even in the control without herbicide application, therefore only the weed control data of the interrow are presented (Figure 6). Weed control with sulfentrazone was high (>80\%) at 27 DAA for both rates with applications before subsoiling. This confirms the high sulfentrazone contents found in the soils of these plots (Figure 2). However, weed control decreased $(<50 \%)$ at 70 and 97 DAA. The application after subsoiling resulted in no satisfactory weed control in the experimental area.

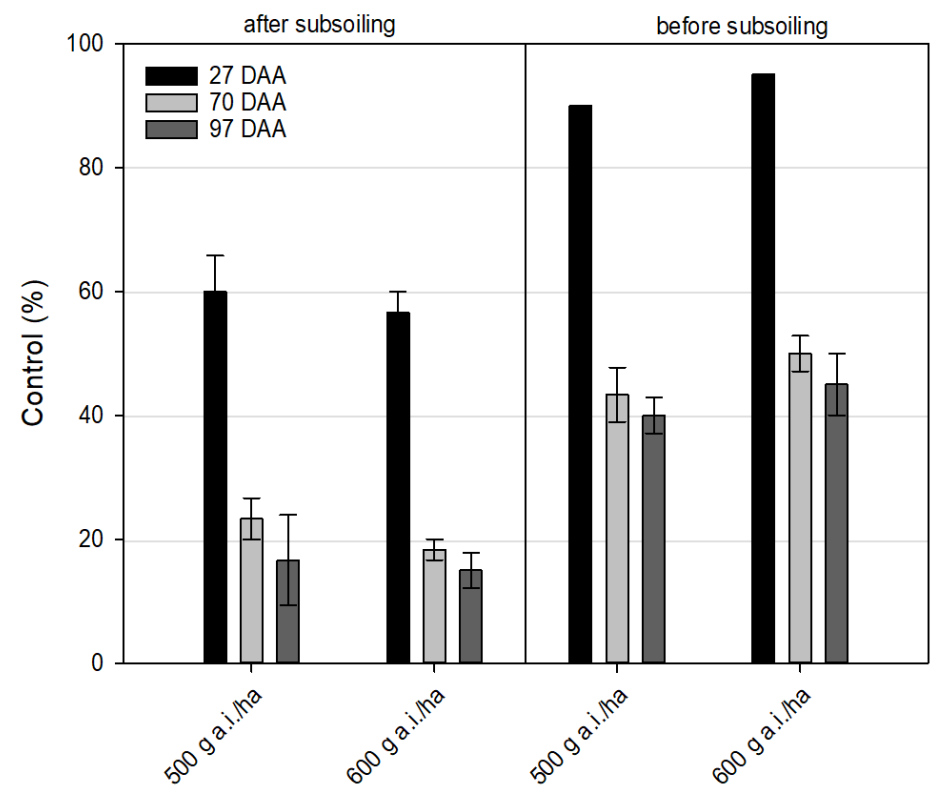

Figure 6. Percentage of weed control in the inter-row, at 37, 70 and 97 days after application, in the area in Paranapanema, SP, Brazil. (Means \pm standard error).

Weed control with sulfentrazone was, in general, more efficient in the area in Itatinga (sandy soil, application in the wet season, with high accumulated rainfall between the evaluations) than that in Paranapanema (clayey soil, application in the dry season, with low accumulated rainfall between the first evaluations at 48 and 27 DAA). Sulfentrazone is more available in the soil solution in sandy soils than in clayey soils, and it is intensely adsorbed to soil colloids in clayey soils (Silva Junior et al., 2016; Monquero et al., 2010). According to Carbonari et al. (2016b), adsorption of sulfentrazone in clayey soils is four-fold that of sandy soils, i.e., the herbicide is four times more available in sandy soils. This may directly affect weed control and selectivity of the herbicide.

\section{CONCLUSIONS}

The highest rates of sulfentrazone used resulted in greater contents of this herbicide in the soil in both evaluated areas. The sulfentrazone presented different dynamics in the evaluated soils. The application of sulfentrazone before subsoiling resulted in greater weed control on inter-row, despite the lower sulfentrazone contents found in the soils in the first evaluation. The sulfentrazone rates and application modes had no effect on the development of eucalyptus plants. It was possible to observe that the doses of $400 \mathrm{~g}$ ha-1 (sandy soil) and $600 \mathrm{~g}$ ha-1 (clay soil) provided higher residual and weed control when applied before subsoiling.

\section{ACKNOWLEDGEMENTS}

The São Paulo Research Foundation funded this research (FAPESP - Number: 2015/09390-1). 


\section{REFERENCES}

Blanco, F. M. G., Velini, E. D., \& Batista Filho, A. (2010). Persistência do herbicida sulfentrazone em solo cultivado com cana-de-açúcar. Bragantia, 69(1), 71-75. http://dx.doi.org/10.1590/S000687052010000100010.

Braga, D. F., Freitas, F. C. L., Rocha, P. R. R., Araujo, A. G. D., \& Melo, V. C. (2016). Leaching of sulfentrazone in soils from the sugarcane region in the northeast region of Brazil. Planta Daninha, 34(1), 161-169. http://dx.doi.org/10.1590/S0100-83582016340100017.

Carbonari, C. A., Gomes, G. L., Trindade, M. L., Silva, J. R., \& Velini, E. D. (2016a). Dynamics of sulfentrazone applied to sugar cane crop residues. Weed Science, 64(1), 201-206. http://dx.doi.org/10.1614/WS-D-14-00171.1.

Carbonari, C. A., Miranda, L. G., Gomes, G. L. G. C., Picoli Junior, G. J., Matos, A. K. A., \& Velini, E. D. (2016b). Differential tolerance of eucalyptus clones to sulfentrazone applied in different soil textures. Scientia Forestalis, 44(109), 9-18. http://dx.doi.org/10.18671/scifor.v44n109.01.

Carbonari, C. A., Velini, E. D., Gomes, G. L. G. C., Takahashi, E. N., \& Araldi, R. (2012). Seletividade e absorção radicular do sulfentrazone em clones de eucalipto. Planta Daninha, 30(1), 147-153. http://dx.doi.org/10.1590/S0100-83582012000100017.

Cruz, M. B., Alves, P. L. D. C. A., Karam, D., \& Ferraudo, A. S. (2010). Capim-colonião e seus efeitos sobre o crescimento inicial de clones de Eucalyptus × urograndis. Ciência Florestal, 20(3), 391-401. http://dx.doi.org/10.5902/198050982054.

Ferreira, G. L., Saraiva, D. T., Queiroz, G. P., Silva, D. V., Pereira, G. A. M., Ferreira, L. R., Oliveira Neto, S. N., \& Mattiello, E. M. (2016). Eucalypt growth submitted to management of Urochloa spp. Planta Daninha, 34(1), 99-107. http://dx.doi.org/10.1590/S0100-83582016340100010.

Freitas, M. A. M., Passos, A. B. R. J., Torres, L. G., Moraes, H. M. F., Faustino, L. A., Rocha, P. R. R., \& Silva, A. A. (2014). Sorção do sulfentrazone em diferentes tipos de solo determinada por bioensaios. Planta Daninha, 32(2), 385-392. http://dx.doi.org/10.1590/S0100-83582014000200016.

Garau, A. M., Ghersa, C. M., Lemcoff, J. H., \& Barañao, J. J. (2009). Weeds in Eucalyptus globulus subsp. maidenii (F. Muell) establishment: effects of competition on sapling growth and survivorship. New Forests, 37(3), 251-264. http://dx.doi.org/10.1007/s11056-008-9121-8.

Gatto, A., Barros, N. D., Novais, R. D., Costa, L. D., \& Neves, J. C. L. (2003). Efeito do método de preparo do solo, em área de reforma, nas suas características, na composição mineral e na produtividade de plantações de Eucalyptus grandis. Revista Árvore, 27(5), 635-646. http://dx.doi.org/10.1590/S010067622003000500006.

Indústria Brasileira de Árvores - IBÁ. (2017). Relatório 2017. São Paulo: IBÁ. Retrieved in 20139 March 12, from https://iba.org/images/shared/Biblioteca/IBA_RelatorioAnual2017.pdf

Machado, A. F. L., Ferreira, L. R., Santos, L. D. T., Santos, J. B., Ferreira, F. A., \& Viana, R. G. (2009). Absorção, translocação e exsudação radicular de glyphosate em clones de eucalipto: clones. Planta Daninha, 27(3), 549-554. http://dx.doi.org/10.1590/S0100-83582009000300016.

Martinez, C. O., De Souza Silva, C. M. M., Fay, E. F., Abakerli, R. B., Maia, A. D. H. N., \& Durrant, L. R. (2008). The effects of moisture and temperature on the degradation of sulfentrazone. Geoderma, 147(1-2), 56-62. http://dx.doi.org/10.1016/j.geoderma.2008.07.005.

Martinez, C. O., Silva, C. M., Fay, E. F., Abakerli, R. B., Maia, A. H., \& Durrant, L. R. (2010). Microbial degradation of sulfentrazone in a Brazilian rhodic hapludox soil. Brazilian Journal of Microbiology, 41(1), 209-217. PMid:24031483. http://dx.doi.org/10.1590/S1517-83822010000100030.

Medeiro, W. N., Melo, C. A. D., Tiburcio, R. A. S., Silva, G. S., Machado, A. F. L., Santos, L. D. T., \& Ferreira, F. A. (2016). Crescimento inicial e concentração de nutrientes em clones de Eucalyptus urophylla $\mathrm{x}$ Eucalyptus grandis sob interferência de plantas daninhas. Ciência Florestal, 26(1), 147-157. http://dx.doi.org/10.5902/1980509821099.

Melo, C. A. D., Medeiros, W. N., Tuffi Santos, L. D., Ferreira, F. A., Tiburcio, R. A. S., \& Ferreira, L. R. (2010). Lixiviação de sulfentrazone, isoxaflutole e oxyfluorfen no perfil de três solos. Planta Daninha, 28(2), 385-392. http://dx.doi.org/10.1590/S0100-83582010000200018.

Monquero, P. A., Silva, P. V., Silva Hirata, A. C., Tablas, D. C., \& Orzari, I. (2010). Leaching and persistence of sulfentrazone and imazapic. Planta Daninha, 28(1), 185-195. http://dx.doi.org/10.1590/S010083582010000100022.

Olivette, M. P. A., Castanho Filho, E. P., Sachs, R. C. C., Nachiluk, K., Martins, R., Camargo, F. P., Angelo, J. A., \& Oliveira, L. H. D. C. L. (2011). Evolução e prospecção da agricultura paulista: liberação da área de pastagem para o cultivo da cana-de-açúcar, eucalipto, seringueira e reflexos na pecuária, 19962030. Informações Econômicas, 41(3), 37-67. 
Passos, A. B. R., Freitas, M. A. M., Gonçalves, V. A., Silva, G. S., Da Silva, A. A., Queiroz, M. E. L., Lima, C. F., \& Silva, D. V. (2015). Leaching of sulfentrazone in soils of reforestation in Brazil. Environmental Earth Sciences, 74(2), 1211-1215. http://dx.doi.org/10.1007/s12665-015-4110-7.

Reddy, K. N., \& Locke, M. A. (1998). Sulfentrazone sorption, desorption, and mineralization in soils from two tillage systems. Weed Science, 46(4), 494-500. http://dx.doi.org/10.1017/S0043174500090950.

Rodrigues, B. N., \& Almeida, F. S. Guia de herbicidas (6. ed.). Londrina: Grafmarke, 2011.

Scalla, R., Matringe, M., Camadro, J. M., \& Labbe, P. (1990). Recent advances in the mode of action of diphenyl ether and related herbicides. Zeitschrift Naturforschung, 45(5), 503-511. http://dx.doi.org/10.1515/znc-1990-0535.

Shaner, D. L. (2012). Field dissipation of sulfentrazone and pendimethalin in Colorado. Weed Technology, 26(4), 633-637. http://dx.doi.org/10.1614/WT-D-12-00037.1.

Silva Junior, A. C., Queiroz, J. R. G., \& Martins, D. (2016). Leaching of sulfentrazone herbicide in soils with different textures. Científica, 44(4), 575-583. http://dx.doi.org/10.15361/1984-5529.2016v44n4p575583.

Sociedade Brasileira da Ciência das Plantas Daninhas - SBCPD. (1995). Procedimentos para instalação, avaliação e análise de experimentos com herbicidas. Londrina: SBCPD.

Author's contributions: CAC, FHK,GLGCG, PSS, GJPJ, EDV: conceptualization, funding acquisition, supervision, writing, formal analysis, methodology, data curation, formal analysis. 